\title{
Assessing Land Use and Land Cover Changes in the Murchison Bay Catchment of Lake Victoria Basin in Uganda
}

\author{
Nicholas Kiggundu $\mathrm{II}^{1}$, Listowel Abugri Anaba ${ }^{1}$, Noble Banadda ${ }^{1,2}$, Joshua Wanyama ${ }^{1} \&$ Isa Kabenge $^{1}$ \\ ${ }^{1}$ Department of Agricultural and Biosystems Engineering, Makerere University, P. O. Box 7062, Uganda \\ ${ }^{2}$ Department of Agricultural and Biosystems Engineering, Iowa State University, 1340 Elings Hall, Ames, Iowa, \\ USA \\ Correspondence: Nicholas Kiggundu II, Department of Agricultural and Biosystems Engineering, Makerere \\ University, P. O. Box 7062, Kampala, Uganda. Tel: 256-772-443-552. E-mail: kiggundu@caes.mak.ac.ug
}

Received: September 20, 2017

Accepted: October 13, 2017

Online Published: January 30, 2018

doi:10.5539/jsd.v11n1p44

URL: https://doi.org/10.5539/jsd.v11n1p44

\begin{abstract}
The Murchison Bay catchment in the northern shoreline of Lake Victoria basin is a high valued ecosystem because of the numerous human-related activities it supports in Uganda. The catchment has undergone tremendous human-induced land use/cover changes, which have not been quantified. This study aimed at quantifying the land use/cover changes as well as the rate at which these changes occurred over the last three decades in the catchment. This was achieved using remote sensing techniques and Geographic Information System (GIS) to analyse and contextualize the changes. To that effect, images of Landsat satellites MSS, TM, $\mathrm{ETM}+$ and OLI were interpreted using supervised image classification technique to determine the land use/land cover changes from 1984 to 2015 . The obtained results indicated that the catchment has undergone huge land use and land cover transformations over the last three decades attributable to rapid population growth and urbanization. The prevailing changes in footprint between 1984 and 2015 were expansions of built-up land ( $20.58 \%$ to $49.59 \%$ ) and open water bodies (not detected in 1984 to $1.74 \%$ ), and decreases in the following sectors: agricultural lands (from $43.88 \%$ to $26.10 \%$ ), forestland (from $23.78 \%$ to $17.49 \%$ ), and wetlands (from $11.76 \%$ to $5.08 \%$ ). The changes pose a threat to the environment and water quality of the Murchison Bay and consequently increases National Water and Sewerage Corporation water treatment costs. Therefore, there is the need to take critical and practical measures to regulate and police land use, water use rights and conserve the environment especially wetlands.
\end{abstract}

Keywords: land use, land cover, Murchison bay catchment, Lake Victoria, Uganda, supervised classification

\section{Introduction}

Land is one of the most vital natural resources that support people's livelihoods and development, hence its use is a fundamental factor of any human activity (Diyer et al., 2013; NEMA, 2009). Land use is any form of human activity on the land with the intention to benefit from the land resources. The increasing demand for this limited resource has put pressure on land and its surface features referred to as land covers and in so doing, have altered the surface cover of land that influence a very diverse collection of environmental processes and properties. According to Olofsson et al. (2013), the impact of land use and land cover change may be felt across a wide spectrum of environmental systems including the atmosphere, hydrology, geomorphology and ecology. Over utilisation of land resources have caused numerous forms of degradation such as loss of biodiversity, deforestation, land and water degradation (Diyer et al., 2013). It is estimated that, about $83 \%$ of the global terrestrial land surface has been affected by the activities of humans and $60 \%$ of the ecosystem degraded over the past half century. The modification of the terrestrial surface of the earth is generally referred as land use and land cover change (Ellis, 2013).

Land use and land cover changes are found to be the most evident indicator of these human footprints and the greatest driver of biodiversity loss and other land degradation forms (Nkonya et al., 2012). The disturbance of the land through these human activities has wide ranging and long-term consequences that affect important ecosystem processes and services ( $\mathrm{Wu}, 2008)$.

The collective impact of land use and cover changes on the environment is a subject of concern to both 
developing and developed nations as it affects sustainable development (Akhter, 2006). Poor use of land especially in developing countries has led to huge proportions of land being degraded, reduction in food production and it is now a threat to livelihood (Maitima et al., 2010). Rapid urbanization, predominantly in developing worlds, is one of the critical issues and visible anthropogenic force that has brought so much changes in urban landscape and land cover pattern around the globe.

The Lake Victoria basin has experienced huge ecological changes over the past eight decades. According to Kinuthia-Njenga (2008) and Muhati et al. (2008), the dramatic environmental changes experienced by the Lake Victoria over the past are as a result of land use and land cover changes, poor agricultural developments, industrialisation, destruction of critical wetlands among others. While some of these factors are undergoing expansion around the catchments of the lake, others are intensifying. Land use change is noted to be one of the factors correlating with the worsening quality of water in the lake (Kimwaga et al., 2012). The changes are due to fast population growth and conversion of lands along the shores for different purposes contributing to the increasing water quality deterioration in the lake. Although some studies (Berakhi, 2013; Kimwaga et al., 2012; Maitima et al., 2010; Mango et al., 2011; Masanja, 2013; Mati at al., 2005; Muhati et al., 2008; Musamba et al., 2011) have quantified land use and cover changes in some catchments of the lake, yet there are other catchments for instance, the Murchison Bay catchment of the lake situated in Uganda with little or no information about the extent of land use and land cover change. For instance, in parts of the Murchison Bay catchment of the Lake Victoria, different studies (Akurut et al., 2014; Banadda et al., 2009; Haande et al., 2011; JTR, 2015; Mbabazi et al., 2010) have reported the rising levels of pollution and its increasing impact as a result of expansion of Kampala city, wetland area transformations, poor agricultural practices and deforestation. However, the magnitude and the rate of these land use and cover changes have not been quantified in the Murchison Bay catchment. With land use and land cover changes having an effect on the ecosystem that is sustaining human needs and development, understanding these surface processes is necessary for minimizing the continuous adverse impact of these changes (Gbenga, 2008). It is against this background that this paper seeks to quantify the changes occurred over the years from 1984 to 2015.

\section{Method}

\subsection{Study Area}

The Murchison Bay is an extension of Lake Victoria situated in the south-east of Kampala city which lies between latitudes $00^{\circ} 10^{\prime} 00^{\prime \prime} \mathrm{N}-00^{\circ} 30^{\prime} 00^{\prime \prime} \mathrm{N}$ and longitudes $32^{\circ} 35^{\prime} 00^{\prime \prime} \mathrm{E}-32^{\circ} 50^{\prime} 00^{\prime \prime} \mathrm{E}$ with average elevation of $1224 \mathrm{~m}$ above sea level. As shown in Figure 1, this study considered the largest watershed of the Murchison Bay that drains through the Nakivubo Channel to the Murchison Bay. The Nakivubo channel runs from the central Kampala district passing through densely populated slums, industrial settlements and markets before discharging its water to the Lake Victoria at the Murchison Bay. The watershed covers the Nakawa, Makindye, Rubaga and Central divisions within the capital city of Uganda with an area of about $40.9 \mathrm{~km}^{2}$. The population of Kampala city increased from 0.8 million in 1991 to about 1.5 million in 2014 (UBOS, 2014). The Murchison Bay is a very important feature of the ecosystem besides being central to the development and health of above one million people in its catchment area. It is a source of basic amenities such as food, water, employment, transport and recreation to the people in the catchment.

The catchment is within the equatorial belt, and has a moist sub-humid climate. It receives a bi-seasonal rainfall in the periods of March to May and September to November (Kansiime \& Nalubega, 1999). Mean monthly precipitation ranges from $24 \mathrm{~mm}$ in January to about $154 \mathrm{~mm}$ in October with mean annual precipitation of about $1293 \mathrm{~mm}$. 


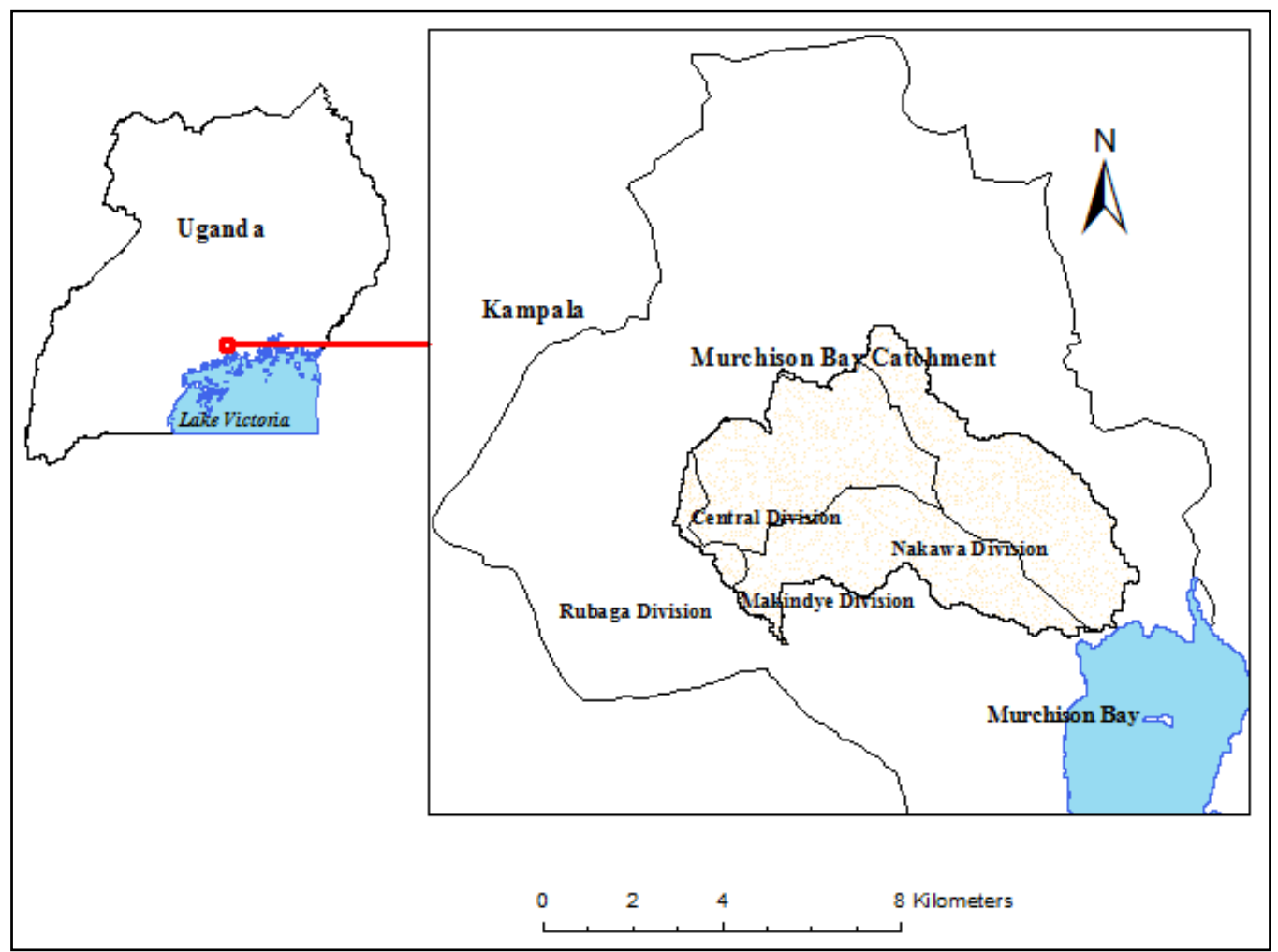

Figure 1. The Murchison Bay Watershed

\subsection{Data Collection}

\subsubsection{Data Acquisition}

In determining the magnitude of land use and land cover changes, different remote sensing data from various sources were used in this study. The data used were Landsat images, digital elevation model (DEM), and Google Earth images.

Four Landsat satellite images of 1984, 1995, 2003 and 2015 were acquired from the Earth Resources Observation and Science (EROS) centre of United States Geological Survey (USGS) Earth explorer (http://www.earthexplorer.usgs.gov/) in raw unprocessed form. The characteristics of Landsat images used in the study are shown in Table 1. The path and row for the scenes covering the study area are 171 and 60 respectively. Images from Landsat satellites are used at regional or landscape scale to study any changes (NASA, 2007). These changes may be vegetation dynamics by Normalized Difference Vegetation Index (NDVI), hydrology, permafrost, dynamics, and land-use by wildlife and humans (Forbes et al., 2009; Myers-Smith et al., 2011).

A number of factors were considered in selecting the Landsat images for the study. These include the time of the year the images were acquired, the degree of cloud cover, and the availability of Landsat images for the intended year (Berakhi, 2013) as well as quality of the images acquired.

Table 1. Characteristics of Landsat satellite imagery used in the study

\begin{tabular}{lllll}
\hline Landsat Scene & Sensor & Date acquired & CC* (\%) & $*$ Res. \\
\hline LM51710601984181AAA03 & Landsat 5 MSS & $29-06-1984$ & 5.00 & 60 \\
LT51710601995019XXX02 & Landsat 5 TM & $19-01-1995$ & 0.00 & 30 \\
LE71710602003033SGS00 & Landsat 7 ETM & $02-02-2003$ & 0.00 & 30 \\
LC81710602015058LGN00 & Landsat 8 OLI_TIRS & $27-02-2015$ & 0.34 & 30 \\
\hline
\end{tabular}

$\mathrm{CC}^{*}=$ Cloud cover, ${ }^{*}$ Res. $=$ Resolution 
Images with minimum cloud cover were selected. However, there were certain years of interest without good images or there were data gaps. For those years without good images, the closest year with good images to the year of interest either previous or the following year was considered. For instance, though the study wanted to look at land use cover changes from 1985 to 2015 at ten years interval, due to lack of good scenes for 1985 and the data gaps for 2005 due to the failure of Landsat 7 ETM Scan Line Corrector (SLC) in May 2003 (Storey et al., 2005), they were substituted for 1984 and 2003, respectively.

The topography of a watershed is defined by its digital elevation model. The STRM DEM of the study area thus the Central region of Uganda at a resolution of 1 arc second $(30 \mathrm{~m} \times 30 \mathrm{~m})$ was downloaded from USGS website (http://gdex.cr.usgs.gov/gdex/). The DEM was used to delineate the Murchison Bay catchment in ArcGIS. Other GIS data such as the location of existing built-ups, forest, swamps and other physical features were derived with the aid of Google Earth images (Abebe, 2013; Olofsson et al., 2014; Olofsson et al., 2013).

\subsection{Processing of Landsat Images}

The processing and classification of the Landsat images were done using GIS tools in ArcGIS 10.1. The unprocessed image bands obtained from the Landsat satellites were imported and combined to form a single multispectral image by using the composite band tool in ArcGIS. The area of interest was clipped out from the composite image and used to classify land use/covers.

\subsection{Land Use and Land Cover Classification}

The images were classified based on observations made at the study site and in accordance with Anderson (1976) Level I generalised classification system using maximum likelihood supervised classification tool in ArcGIS. The Level I classification system is appropriate for gathering general land use information and it is made for use with Landsat data.

The land use covers identified were put into five major classes which are open water bodies, agricultural lands, forestland, wetlands and built-up area. Open water bodies include lake, reservoirs, streams and canals while built-up area consists of residential, industrial, commercial, parking lots, construction sites, mixed urban, road and railway networks. Agricultural land is made up of cropland and grassland whereas forestland comprises of a mixed deciduous and evergreen forestland. Figure 2 presents the methodology adopted in classifying the land use and land covers.

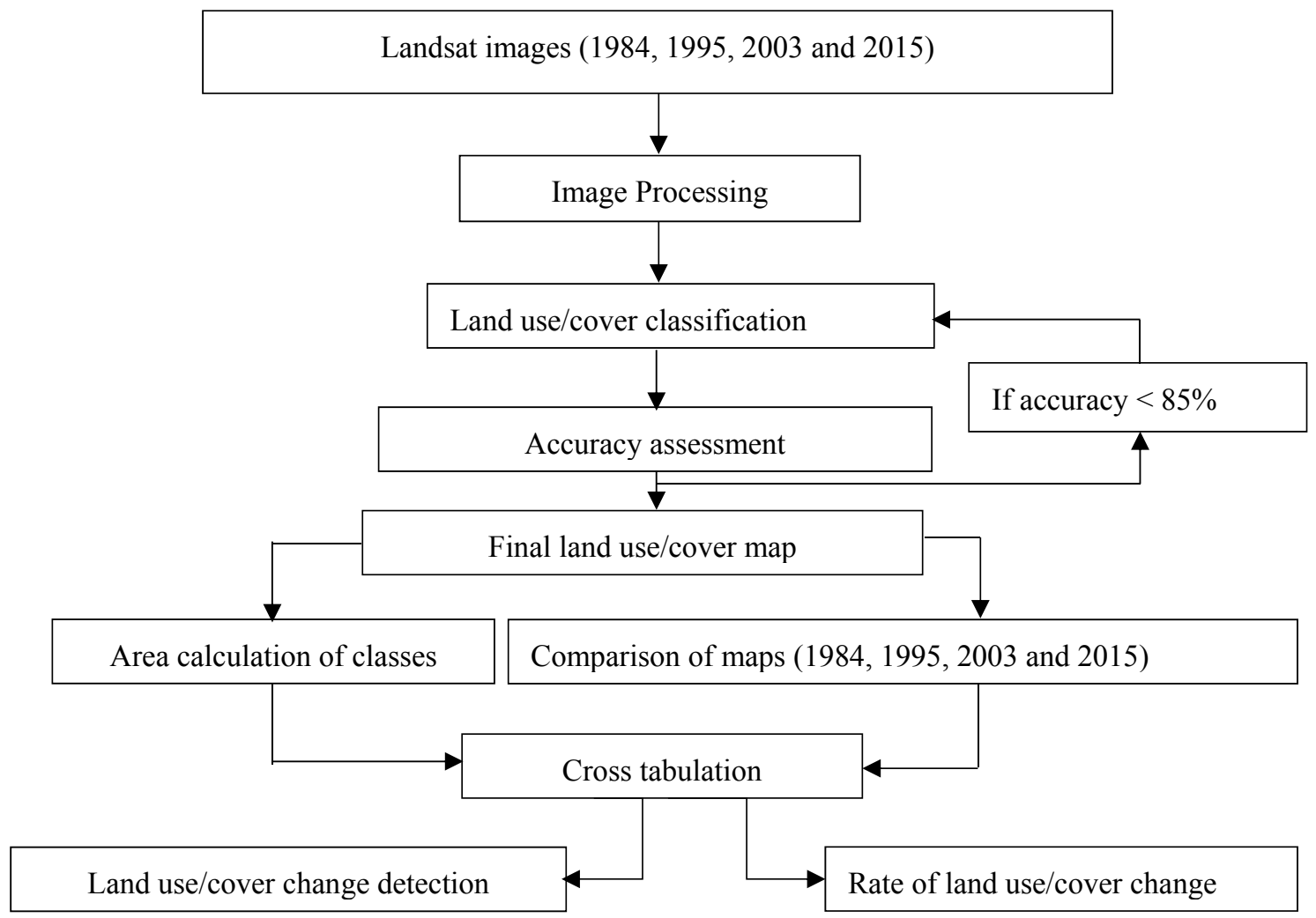

Figure 2. Flow chart of methodology used in classifying land use land cover changes 


\subsubsection{Accuracy Assessment}

Prior to the classification stage, a ground-truth data was collected from the study site to ascertain the reality on the ground and to help in assessing the accuracy of the classified maps. In this study, accuracy assessment was done for 2003 and 2015 land use cover maps by using 150 randomly sampled reference data pixels taken from high resolution imagery in Google Earth (Abebe, 2013; Han et al., 2015; Hegazy \& Kaloop, 2015; Megahed et al., 2015; Minu \& Shetty, 2015; Olofsson et al., 2014; Olofsson et al., 2013; Romo-Leon et al., 2014). Classification accuracy of 1984 and 1995 could not be assessed due to difficulties in getting any aerial photographic coverage or any historical reference data to rely on. It was assumed that the accuracy assessment of 2003 and 2015 maps would be satisfactory to provide an indication for the accuracy of 1984 and 1995 classified maps. Figure 3 shows the Google Earth images of the study area. According to Olofsson et al. (2014), to ensure higher quality of a reference classification as compared to the map classification, the ground data source should be of higher quality than what is used to produce the map classification since it could create some biasness.

The accuracy was assessed by determining the overall accuracy, user's accuracy, producer's accuracy, and the Kappa coefficient derived from the most common (Berakhi, 2013) and most effective (Congalton, 1991) technique called the error matrix to determine the accuracy and reliability of the maps produced. An error matrix is a square display of numbers designed in rows and columns which express the number of sample unit assigned to a particular class in relation to the actual class as verified on the ground. The columns are the referenced data while the rows are the classifications generated from the Landsat data.

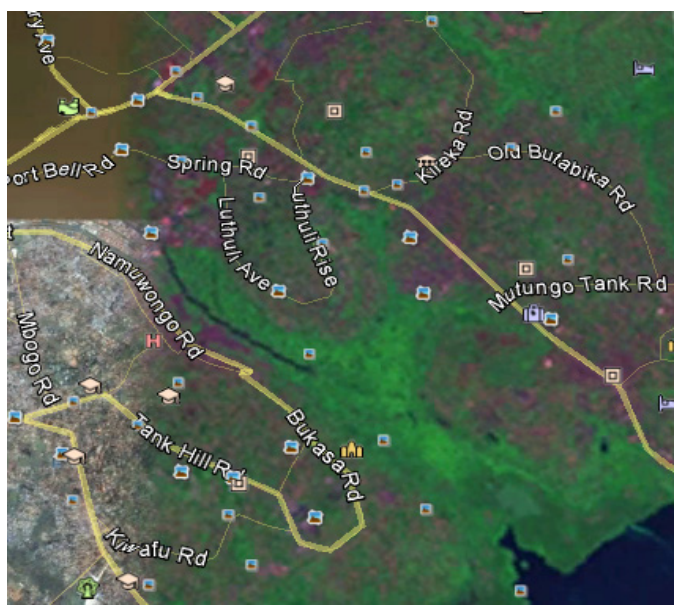

2003

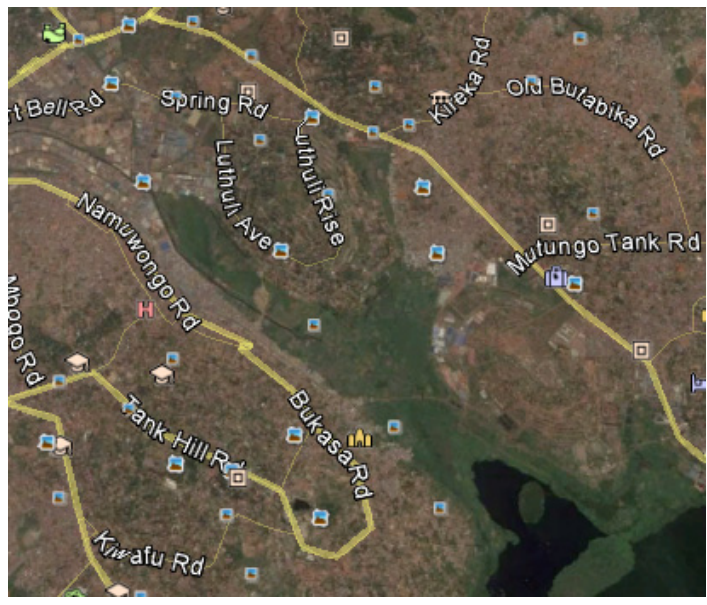

2015

Figure 3. Google Earth image of the study area in 2003 and 2015

The producer's accuracy was calculated by dividing the number of accurate classified pixels in a category to the number of reference set pixels in that category while the user's accuracy was determined by dividing the number of accurately classified pixels in each category by the row total. The overall classification accuracy is the proportion of correctly classified samples of an error matrix. It was calculated by dividing the total number of correctly classified samples by the total number of referenced samples. The overall accuracy was calculated using Equation 1 by Akhter (2006).

$$
\text { Overall accuracy }=\frac{1}{\mathrm{~N}} \sum_{i=1}^{n} x_{i i}
$$

Where,

$\mathrm{x}=$ individual cell values, $\mathrm{x}_{\mathrm{ii}}=$ the total number of observations in row $\mathrm{i}$ and column $\mathrm{i}, \mathrm{n}=$ total number of classes, $\mathrm{N}=$ total number of samples.

The value of the overall Kappa coefficient (Kc) was calculated using Equation 2 by Congalton (1991). 


$$
K_{c}=\frac{N \sum_{i=1}^{r} x_{i i}-\sum_{i=1}^{r}\left(x_{i+} * x_{+i}\right)}{N^{2}-\sum_{i=1}^{r}\left(x_{i+} * x_{+i}\right)}
$$

Where $\mathrm{Kc}=$ Kappa coefficient, $\mathrm{N}=$ total number of samples, $\mathrm{x}_{\mathrm{ii}}=$ sum of correctly classified pixel, $\mathrm{r}$ is the number of rows in the matrix, $x_{i+}$ and $x_{+i}$ are the marginal totals of row $i$ and column $i$ respectively.

\subsubsection{Land Use and Land Cover Change Detection and Analysis}

Detection of land use and land cover changes require satellite imageries of two different years as a minimum (Brar, 2013; Ndulue et al., 2015). In that regard, post classification comparison technique was used where independently classified images were compared to determine the changes. It is the most obvious approach (Singh, 1989) for comparing data from different sources and dates. To determine the changes that has occurred from 1984 to 2015 , the area of each land cover classified for each study year was computed and subsequently compared at four intervals thus, 1984-1995, 1995-2003, 2003-2015 and 1984-2015. Thus, the observed change was the difference in area of the various years.

\subsubsection{Assessment of the Rate of Land Use and Land Cover Change}

The rate of land use/cover change based on area and by percentage were estimated for the different classes using Equation 3, 4 and 5.

$$
\begin{gathered}
\% \text { of land use change }=\frac{\mathrm{A}_{\text {year } \mathrm{i}+1}-\mathrm{A}_{\text {year } \mathrm{i}}}{\sum_{\mathrm{i}=1}^{\mathrm{n}} \mathrm{A}_{\text {year } \mathrm{i}}} * 100 \\
\text { Annual rate of change }=\frac{\mathrm{A}_{\text {year } \mathrm{i}+1}-\mathrm{A}_{\text {year } \mathrm{i}}}{t_{\text {years }}} \\
\% \text { annual rate of land use change }=\frac{\mathrm{A}_{\text {year } \mathrm{i}+1}-\mathrm{A}_{\text {year } \mathrm{i}}}{\sum_{\mathrm{i}=1}^{\mathrm{n}} \mathrm{A}_{\text {year } \mathrm{i}} * t_{\text {years }}} * 100
\end{gathered}
$$

Where Ayear $\mathrm{i}=$ area of cover $\mathrm{i}$ at the first date, $\mathrm{A}_{\text {year } i+1}=$ area of cover at the second date, and tyears = period between the first and second dates, $\mathrm{n}=$ the number of years within an interval

\section{Results}

\subsection{Land Use and Land Cover Classes in the Murchison Bay Catchment}

The land use and land cover results for 1984, 1995, 2003 and 2015 of the Murchison Bay catchment are summarized in Table 2 and Figure 4.

Table 2. Land use-cover classes and their proportions in the Murchison Bay Catchment

\begin{tabular}{lrrrrrrrr}
\hline & \multicolumn{2}{c}{1984} & \multicolumn{2}{c}{1995} & \multicolumn{2}{c}{2003} & \multicolumn{2}{c}{2015} \\
Land use-cover & \multicolumn{1}{c}{ Area (ha) } & \multicolumn{1}{c}{$\%$} & Area (ha) & \multicolumn{1}{c}{$\%$} & Area (ha) & \multicolumn{1}{c}{$\%$} & Area (ha) & \multicolumn{1}{c}{$\%$} \\
\hline Open water & 0.00 & 0.00 & 9.00 & 0.22 & 10.62 & 0.26 & 71.09 & 1.74 \\
Agricultural land & 1794.69 & 43.88 & 1326.24 & 32.42 & 1502.43 & 36.73 & 1067.52 & 26.1 \\
Forestland & 972.66 & 23.78 & 1274.23 & 31.15 & 568.81 & 13.91 & 715.5 & 17.49 \\
Wetland & 481.10 & 11.76 & 395.50 & 9.67 & 409.62 & 10.01 & 207.78 & 5.08 \\
Built-up area & 841.85 & 20.58 & 1085.34 & 26.53 & 1598.81 & 39.09 & 2028.41 & 49.59 \\
Total & 4090.30 & 100 & 4090.30 & 100 & 4090.30 & 100 & 4090.30 & 100 \\
\hline
\end{tabular}




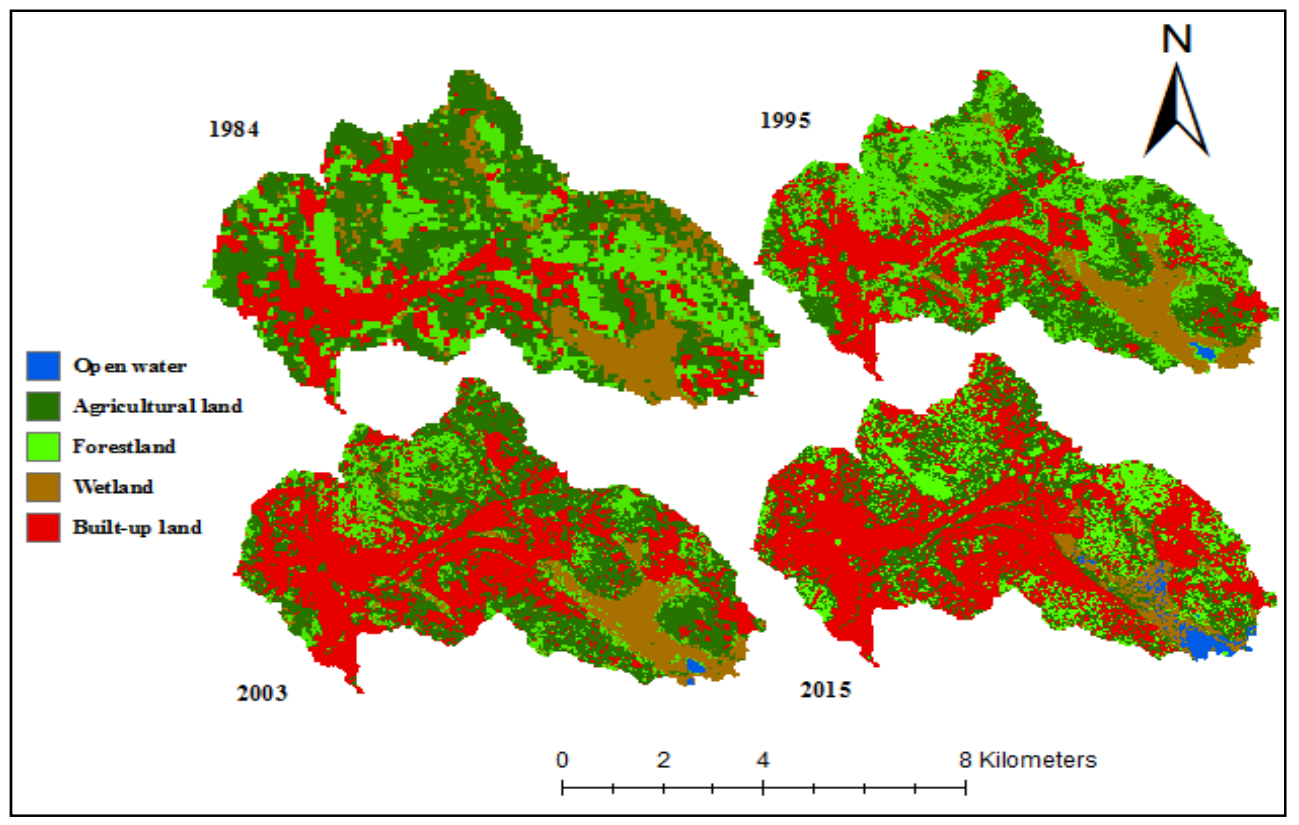

Figure 4. Land use/cover classified map of the Murchison Bay catchment

\subsection{Accuracy of Classified Land Use-Cover Classes}

Table 3 and Table 4 show the accuracy assessment results of each of the land use and cover types for 2003 and 2015. The overall accuracy achieved for 2003 and 2015 maps were $88.67 \%$ and $86.67 \%$ with Kappa coefficient of 0.85 and 0.82 respectively.

Table 3. Results of accuracy assessment for 2003 land use and land cover classification

\begin{tabular}{lcccc}
\hline Land use cover & Producer's accuracy (\%) & User's accuracy $(\%)$ & Overall accuracy $(\%)$ & $\mathrm{K}_{\mathrm{c}}$ \\
\hline Open water & 87.50 & 87.50 & & \\
Agricultural land & 86.11 & 81.58 & & \\
Forestland & 91.67 & 94.29 & & \\
Wetland & 80.00 & 76.19 & & \\
Built-up land & 92.00 & 95.83 & & \\
\hline
\end{tabular}

Table 4. Results of accuracy assessment for 2015 land use and land cover classification

\begin{tabular}{lcccc}
\hline Land use-cover & Producer's accuracy $(\%)$ & User's accuracy $(\%)$ & Overall accuracy $(\%)$ & $\mathrm{K}_{\mathrm{c}}$ \\
\hline Open water & 83.33 & 83.33 & & \\
Agricultural land & 75.00 & 75.00 & 86.67 & 0.82 \\
Forestland & 86.00 & 91.49 & & \\
Wetland & 70.00 & 70.00 & & \\
Built-up land & 96.30 & 91.23 & & \\
\hline
\end{tabular}

$\mathrm{Kc}=$ Kappa coefficient

\subsection{Land Use and Land Cover Changes in the Murchison Bay Catchment}

The results of land use and land cover changes from 1984 - 2015 are presented in Figure 5 while the annual rate at which each land use cover increased within the same period is shown in Figure 6. 


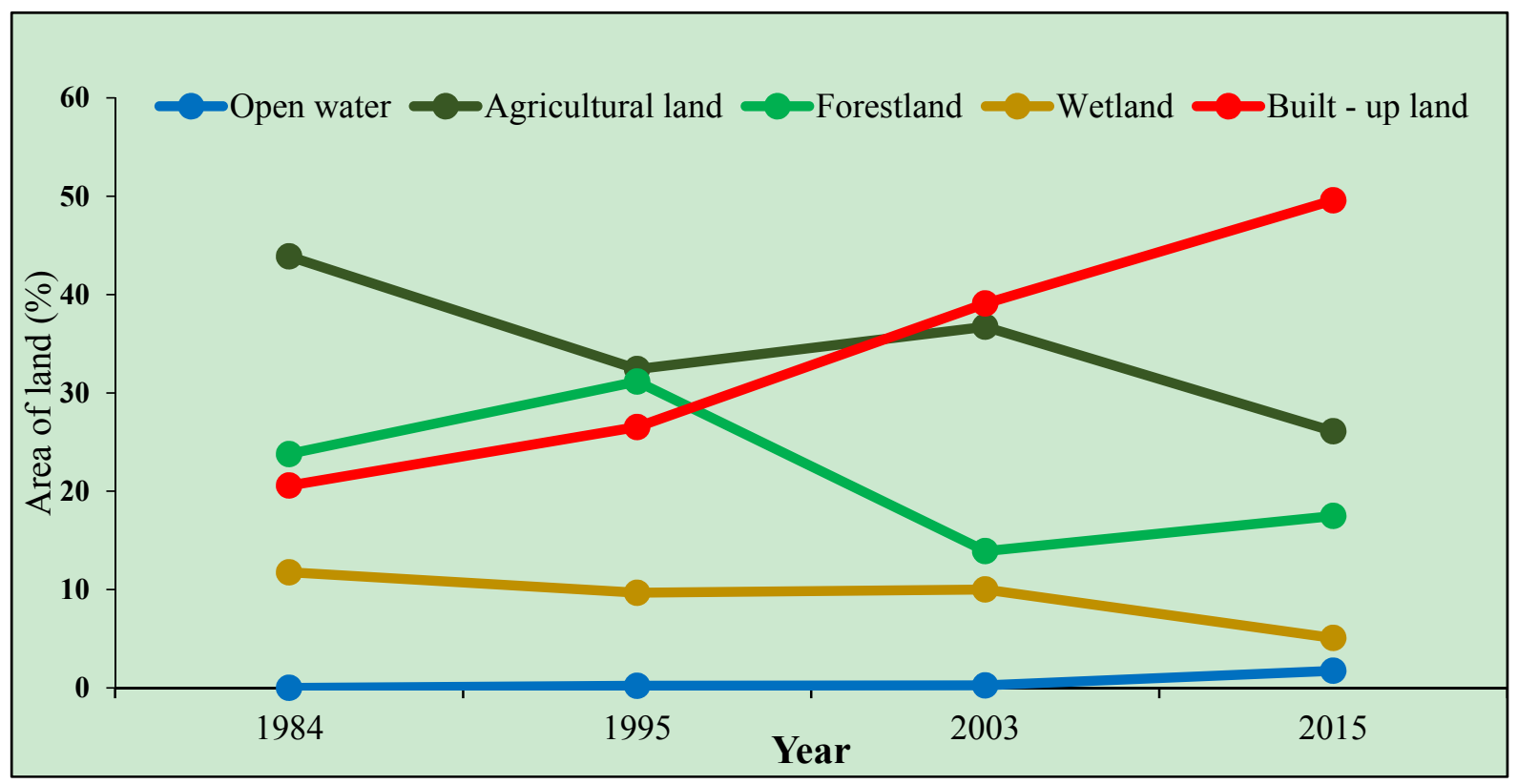

Figure 5. Land use - cover changes of the Murchison Bay catchment from 1984 - 2015

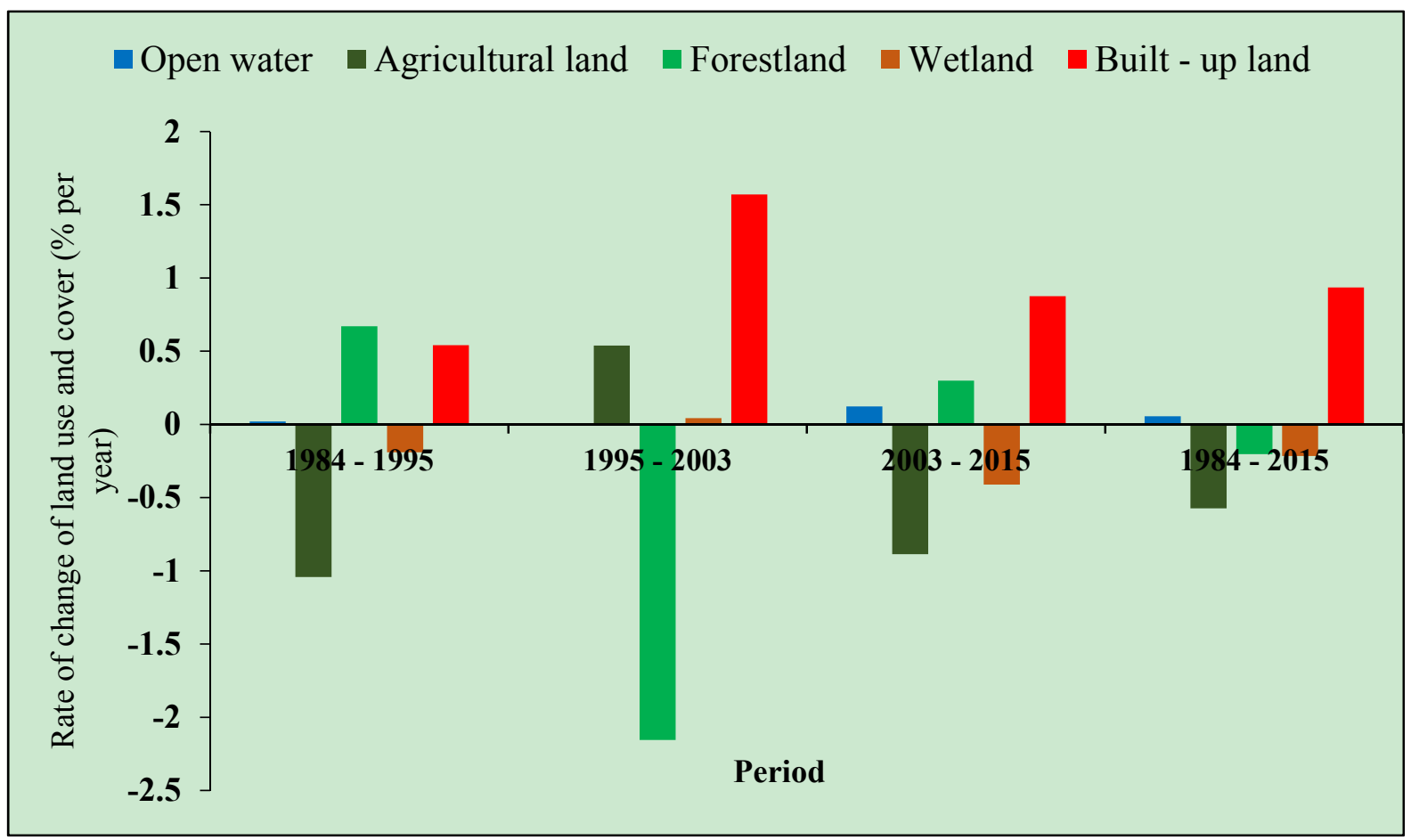

Figure 6. Annual rate of land use - cover changes in the Murchison Bay Catchment from 1984 to 2015

\section{Discussion}

The most dominant land use covers found to have gained in size of area over the years were built-up land and open water bodies while forestland, agricultural land and wetlands shrank in size (Figure 6).

The analysis revealed that built-up land, forestland and wetland increased by 243 ha, 302 ha and 9 ha respectively between the period of 1984 and 1995 . Within the same period, agricultural land and wetland reduced by 468 ha and 86 ha respectively. Between 1995 and 2003, built-up land, agricultural land, wetland and open water bodies increased by 513 ha, 176 ha, 14 ha and 2 ha respectively while forestland declined by 705 ha. 
The land use/covers that gained in area from 2003 to 2015 were built-up land which increased by 430 ha, forestland increased by 147 ha and open water bodies which increased by 60 ha. Throughout the whole period from 1984 to 2015 considered in this study, built-up land had the highest increment by 1187 ha while the highest lost land use/cover is agricultural land.

The period which experienced the highest land use/cover change was from 1995 to 2003 in which both built-up and agricultural lands increased by 513 ha and 176 ha respectively. This could be ascribed to the rapid population growth rate, developed road network and infrastructure, and high rural urban migration that occurred at that time. The trend is in line with the population growth rate of Kampala noted within the same period. According to UBOS (2014), the population of Kampala in 1991 was about 800000 and by 2002, it had increased by $50 \%$. As population increases, the need for more housing facilities and the demand for food are expected to increase correspondingly. This could possibly be the reason that caused the expansion of agricultural lands between 1995 and 2003. The combine effect of the need for built-ups and food caused forestland which was increasing at a rate of $0.67 \%$ per year (Figure 6) between 1984 and 1995 to decline at a rate of $2.16 \%$ per year. The observations are consistent with that of Abebe (2013) who studied the urban growth rate of Kampala and its environs from 1989 to 2010. Abebe (2013) observed that, between 1995 and 2003, built-up area in the whole of Kampala had increased by $112 \%$ while $60 \%$ and $31 \%$ in 1989 to 1995 and 2003 to 2010 respectively. Abebe (2013) related the change to land tenure systems in which the 1995 constitution of Uganda and 1998 Land Act in Uganda gave legal credit private land owners to leasehold or freehold tenures. The 1998 Land Act vests the ownership of all land in Uganda in its citizens, and sets out the tenure system under which the land can be owned. Most of the land in Uganda is under customary tenure, which in some cases implies communal utilization. In some areas, particularly within wetlands there are often spaces where access is not controlled. These open accesses are the areas where land degradation has occurred most.

The results found in this study are also consistent with that of Twesigye et al. (2011) who observed that, built-up was increasing while forestland is decreasing around the Nakivubo wetland which is within the area studied. However, the extent of change differ due to the area of land considered and the classification method used. It was only in the same 1995 - 2003 period that wetlands for the first time, increased by 14 ha representing $0.34 \%$ and at an annual rate gain of $0.04 \%$. This could be attributed to the positive results from a ban on large scale wetland drainage, to enable the process of formulation of a National Wetlands Conservation and Management policy by government of Uganda in 1986 (Turyahabwe et al., 2013).

Although, the population of Kampala in 2002 was about 1.2 million which increased to about 1.5 million in 2014, the period between 2003 and 2015 had built-up land been increased by 429.60 ha which is almost equal to the period from 1995 to 2003. Meanwhile, agricultural land, forestland and wetlands declined within 2003 and 2015 period. This could be related to the period when more industries and factories were been setup. This also means that the exploding population largely involved in industry and sale of goods and services as opposed to agriculture. This is contrary to the results of Turyahabwe et al. (2013) that farmland formed the most dominant land use/cover between 2000 and 2011 accounting for wetland losses in the Lake Victoria crescent in Kampala city. This is because the period coincides when urbanisation was increasing in the two places. The period between 2003 and 2015 also experienced an increasing growth of forestland which could be attributed to afforestation and conservation efforts to restore the environment. A similar observation was noted by Wasige et al. (2013). Also, as people tend to grow trees around their residential and workplaces, it contributes to increasing the vegetative cover of the area.

As noted in this study, trends in population growth, land use policy changes and economic developments in relation to infrastructure and industrialisation were most likely the impelling causes of the observed land use-cover changes. Urbanisation has caused a significant negative impact on the environment in the catchment as it has created permanent impervious layers which reduces infiltration and percolation of water to the underground increasing surface runoff and causing perennial flooding within the catchment. Wastewater and other pollutants discharged from industrial setup have also increased the quantity of sediments and nutrients transported into the Lake Victoria from the catchment studied (Anaba et al., 2017). Encroachment on wetlands that have for long acted as filters and traps pollution discharges from the catchment (JTR, 2015; Kansiime \& Nalubega, 1999) area have lost its function as a buffer zone. The changes in land use and cover have contributed to the deteriorating water quality in the Lake Victoria which is serving the people around the catchment in different capacities such as drinking water, employment, recreation, food and transport (Banadda et al., 2009). Though, urbanization cannot be controlled as population is expected to increase, right decisions such as installation of water harvesting systems on houses, protection of buffer zones, proper waste disposal and drainage systems, clean production in the industries adjacent to the lake need to be made and implemented in 
order to protect the environment.

\section{Conclusions}

Land use and land cover change is one of the factors that contributed enormously to the deterioration of water quality in Lake Victoria. In this study, the magnitude of land use and land cover changes in the Murchison Bay catchment of the Lake Victoria from 1984 to 2015 were quantified using remote sensing technique. The prevailing changes in footprint between 1984 and 2015 were expansions of built-up land (20.58\% to 49.59\%) and open water bodies (not detected in 1984 to $1.74 \%$ ), and decreases in the following sectors: agricultural lands (from $43.88 \%$ to $26.10 \%$ ), forestland (from $23.78 \%$ to $17.49 \%$ ), and wetlands (from $11.76 \%$ to $5.08 \%$ ). The findings show that the Murchison Bay catchment has undergone huge and different land use/cover transitions over the past three decades from its former agricultural and forest dominated lands to its current dominated built-up land. The expansion of built-up land is as a result of the increasing population around its environs causing the need for settlements and the socio-economic development of the area. The land use/cover transformations have had a negative environmental impact with increased surface runoff, pollution discharges and sediment transport depletions from upland, and increased nutrient loadings from industries in the catchment. All these from the catchment ends-up into the Lake Victoria threatening its ecosystem and deteriorates its water quality. Therefore, there is the need to take critical measures to regulate land use and conserve the environment in the Murchison Bay catchment.

\section{Acknowledgments}

The authors acknowledge funding from METEGA and RUFORUM towards this research.

\section{References}

Abebe, G. A. (2013). Quantifying urban growth pattern in developing countries using remote sensing and spatial metrics: A case study in Kampala, Uganda: University of Twente Faculty of Geo-Information and Earth Observation (ITC), $108 \mathrm{pp}$.

Akhter, M. (2006). Remote sensing for developing an operational monitoring scheme for the Sundarban Reserved Forest, Bangladesh, $134 \mathrm{pp}$.

Akurut, M., Willems, P., \& Niwagaba, C. (2014). Assessing the influence of Lake Victoria flux on the Inner Murchison Bay water quality. WIT Transactions on Ecology and the Environment, 182, 51-62. https://doi.org/10.2495/WP140051

Anaba, L. A., Banadda, N., Kiggundu, N., Wanyama, J., Engel, B., \& Moriasi, D. (2017). Application of SWAT to assess the effects of land use change in the Murchison Bay Catchment in Uganda. Comput. Water Energy Environ. Eng, 6, 24-40. https://doi.org/10.4236/cweee.2017.61003

Anderson, J. R., Hardy, E. E., Roach, J. T., \& Witmer, R. E. (1976). A Land Use And Land Cover Classification System For Use With Remote Sensor Data. A Revision of the Land Use Classification System as Presented in U.S. Geological Survey Circular 671, 964, 41 pp.

Banadda, E., Kansiime, F., Kigobe, M., Kizza, M., \& Nhapi, I. (2009). Landuse-based nonpoint source pollution: a threat to water quality in Murchison Bay, Uganda. Water Policy, 11(S1), 94-105. https://doi.org/10.2166/wp.2009.106

Berakhi, R. O. (2013). Implication of human activities on land use land cover dynamics in Kagera catchment, East Africa. MSc. Thesis. Southern Illinois University Carbondale, $121 \mathrm{pp}$.

Brar, G. S. (2013). Detection of land use and land cover change with Remote Sensing and GIS: A case study of Punjab Siwaliks. International Journal of Geomatics and Geosciences, 4(2), 296.

Congalton, R. G. (1991). A review of assessing the accuracy of classifications of remotely sensed data. Remote sensing of environment, 37(1), 35-46. https://doi.org/10.1016/0034-4257(91)90048-B

Diyer, M., Namarani, H., \& Elkadiri, A. (2013). Land Use and Land Management Practices in Environmental Perspective, $81 \mathrm{pp}$.

Ellis, E. (2013). Land-use and land-cover change. Eds.Robert Pontius Retrieved July 21, 2014, from http://www.eoearth.org/view/article/51 cbee4f7896bb431f696e92

Forbes, B. C., Stammler, F., Kumpula, T., Meschtyb, N., Pajunen, A., \& Kaarlejärvi, E. (2009). High resilience in the Yamal-Nenets social-ecological system, west Siberian Arctic, Russia. Proceedings of the National Academy of Sciences, 106(52), 22041-22048. https://doi.org/10.1073/pnas.0908286106 
Gbenga, O. E. (2008). Remote Sensing for Agricultural Land Use Changes and Sustainability Monitoring in Sudan. MSc. Thesis. Linkoping University, Sweden, 67 pp.

Haande, S., Rohrlack, T., Semyalo, R. P., Brettum, P., Edvardsen, B., Lyche-Solheim, A., . . Larsson, P. (2011). Phytoplankton dynamics and cyanobacterial dominance in Murchison Bay of Lake Victoria (Uganda) in relation to environmental conditions. Limnologica-Ecology and Management of Inland Waters, 41(1), 20-29. https://doi.org/10.1016/j.limno.2010.04.001

Han, H., Yang, C., \& Song, J. (2015). Scenario simulation and the prediction of land use and land cover change in Beijing, China. Sustainability, 7(4), 4260-4279. https://doi.org/10.3390/su7044260

Hegazy, I. R., \& Kaloop, M. R. (2015). Monitoring urban growth and land use change detection with GIS and remote sensing techniques in Daqahlia governorate Egypt. International Journal of Sustainable Built Environment, 4(1), 117-124. https://doi.org/10.1016/j.ijsbe.2015.02.005

JTR. (2015). Development of a pollution management strategy to improve long term water quality status in the Inner Murchison Bay, Lake Victoria \& initiate implementation of its initiatives (pp. 1-22). Joint Technical Review Situation Analysis Report.

Kansiime, F., \& Maimuna, N. (1999). Wastewater treatment by a natural wetland: the Nakivubo swamp, Uganda: CRC Press, 336pp.

Kimwaga, R., Bukirwa, F., Banadda, N., Wali, U., Nhapi, I., \& Mashauri, D. (2012). Modelling the impact of land use changes on sediment loading into lake victoria using swat model: a case of simiyu catchment tanzania. Open Environ Eng J, 5, 66-76. https://doi.org/10.2174/1874829501205010066

Kinuthia-Njenga, C. (2008). Promoting biodiversity in and around the Lake Victoria basin. UN-HABITAT, 254(20).

Maitima, J. M., Olson, J., Mugatha, S., Mugisha, S., \& Mutie, I. (2010). Land use changes, impacts and options for sustaining productivity and livelihoods in the basin of lake Victoria. Journal of sustainable development in Africa, 12(3), 1520-5509.

Mango, L. M., Melesse, A. M., McClain, M. E., Gann, D., \& Setegn, S. (2011). Land use and climate change impacts on the hydrology of the upper Mara River Basin, Kenya: results of a modeling study to support better resource management. Hydrology and Earth System Sciences, 15(7), 2245. https://doi.org/10.5194/hess-15-2245-2011

Masanja, G. F. (2013). Migration of agro-pastoralists and wetland degradation in Mbalika, Southern Lake Victoria, Tanzania. International Journal of Physical and Social Sciences, 3(9), 150-171.

Mati, B. M., Mutie, S., Home, P., Mtalo, F., \& Gadain, H. (2005). Land use changes in the transboundary mara basin: A threat to pristine wildlife sanctuaries in East Africa. Paper presented at the A Paper presentation at the: 8th International River Symposium, Brisbane, Australia, 36 pp.

Mbabazi, J., Kwetegyeka, J., Ntale, M., \& Wasswa, J. (2010). Ineffectiveness of Nakivubo wetland in filtering out heavy metals from untreated Kampala urban effluent prior to discharge into Lake Victoria, Uganda. African Journal of Agricultural Research, 5(24), 3431-3439.

Megahed, Y., Cabral, P., Silva, J., \& Caetano, M. (2015). Land cover mapping analysis and urban growth modelling using remote sensing techniques in greater Cairo region-Egypt. ISPRS International Journal of Geo-Information, 4(3), 1750-1769. https://doi.org/10.3390/ijgi4031750

Minu, S., \& Shetty, A. (2015). A comparative study of image change detection algorithms in matlab. Aquatic Procedia, 4, 1366-1373. https://doi.org/10.1016/j.aqpro.2015.02.177

Muhati, D. F., Ininda, J. M., \& Opijah, F. J. (2008). Simulation of the Impact of Deforestation on the Rainfall in Lake Victoria Basin. Journal of Kenya Meteorological Society, 2(2), 125-131.

Musamba, E. B., Ngaga, Y. M., Boon, E. K., \& Giliba, R. A. (2011). Impact of socio-economic activities around Lake Victoria: Land use and land use changes in Musoma Municipality, Tanzania. Journal of Human Ecology, 35(3), 143-154. https://doi.org/10.1080/09709274.2011.11906400

Myers-Smith, I. H., Forbes, B. C., Wilmking, M., Hallinger, M., Lantz, T., Blok, D., . . Lévesque, E. (2011). Shrub expansion in tundra ecosystems: dynamics, impacts and research priorities. Environmental Research Letters, 6(4), 045509. https://doi.org/10.1088/1748-9326/6/4/045509

NASA. (2007). Quantifying Changes in the Land Over Time with Landsat. Landsat Classroom Activity 
Retrieved from http://landsat.gsfc.nasa.gov/wp-content/uploads/2013/05/Landsat_QuantifyChanges.pdf, 36pp.

Ndulue, E., Mbajiorgu, C., Ugwu, S., Ogwo, V., \& Ogbu, K. (2015). Assessment of land use/cover impacts on runoff and sediment yield using hydrologic models: A review. Journal of Ecology and The Natural Environment, 7(2), 46-55. https://doi.org/10.5897/JENE2014.0482

NEMA. (2009). Uganda: Atlas of Our Changing Environment. National Environment Management Authority (NEMA), 205 pp. Retrieved from http://www.grida.no/files/publications/uganda-atlas-2009.pdf, 220 pp.

Nkonya, E., Karsenty, A., Msangi, S., Souza, C., Shah, M., Von-Braun, J., ... Park, S. (2012). Sustainable Land Use for The 21 st Century. Sustainable Development in the 21st Century (SD21). United Nations Department of Economic and Social Affairs, Division for Sustainable Development, New York., 82 PP

Olofsson, P., Foody, G. M., Herold, M., Stehman, S. V., Woodcock, C. E., \& Wulder, M. A. (2014). Good practices for estimating area and assessing accuracy of land change. Remote Sensing of Environment, 148, 42-57. https://doi.org/10.1016/j.rse.2014.02.015

Olofsson, P., Foody, G. M., Stehman, S. V., \& Woodcock, C. E. (2013). Making better use of accuracy data in land change studies: Estimating accuracy and area and quantifying uncertainty using stratified estimation. Remote Sensing of Environment, 129, 122-131. https://doi.org/10.1016/j.rse.2012.10.031

Romo-Leon, J. R., van Leeuwen, W. J., \& Castellanos-Villegas, A. (2014). Using remote sensing tools to assess land use transitions in unsustainable arid agro-ecosystems. Journal of arid environments, 106, 27-35. https://doi.org/10.1016/j.jaridenv.2014.03.002

Storey, J., Scaramuzza, P., Schmidt, G., \& Barsi, J. (2005). Landsat 7 Scan Line Corrector-Off Gap-Filled ProductDevelopment. In Proceedings of Pecora, 16, 23-27.

Singh, A. (1989). Review article digital change detection techniques using remotely-sensed data. International journal of remote sensing, 10(6), 989-1003. https://doi.org/10.1080/01431168908903939

Turyahabwe, N., Tumusiime, D. M., Kakuru, W., \& Barasa, B. (2013). Wetland use/cover changes and local perceptions in Uganda. Sustainable Agriculture Research, 2(4), 95. https://doi.org/10.5539/sar.v2n4p95

Twesigye, C. K., Onywere, S. M., Getenga, Z. M., Mwakalila, S. S., \& Nakiranda, J. K. (2011). The impact of land use activities on vegetation cover and water quality in the Lake Victoria watershed. The Open Environmental Engineering Journal, 4(1), 66-77. https://doi.org/10.2174/1874829501104010066

UBOS. (2014). National Population and housing Census. Uganda Bureau of Statistics, 73 pp: Retrieved from http://www.ubos.org/onlinefiles/uploads/ubos/nphe/nphc2014provisionalresultsreport.pdf.

Wasige, J. E., Groen, T. A., Smaling, E., \& Jetten, V. (2013). Monitoring basin-scale land cover changes in Kagera Basin of Lake Victoria using ancillary data and remote sensing. International Journal of Applied Earth Observation and Geoinformation, 21, 32-42. https://doi.org/10.1016/j.jag.2012.08.005

Wu, J. (2008). Land Use Changes: Economic, Social and Environmental Impacts. Agricultural and Applied Economics Association, 23(4), 6-10.

\section{Copyrights}

Copyright for this article is retained by the author(s), with first publication rights granted to the journal.

This is an open-access article distributed under the terms and conditions of the Creative Commons Attribution license (http://creativecommons.org/licenses/by/4.0/). 